\title{
Kecemasan Orang Tua Yang Memiliki Anak Dengan Penyakit Kanker Selama Pandemi Covid-19
}

\author{
Salsabila Putri Aulia ${ }^{1}$, Hellena Deli ${ }^{1}$, Wan Nishfa Dewi ${ }^{1}$ \\ ${ }^{1}$ Fakultas Keperawatan, Jurusan Keperawatan, Universitas Riau \\ Corresponding author: deli.hellena12@gmail.com
}

\begin{abstract}
ABSTRAK
Latar Belakang: pada masa pandemi Covid-19, banyak orang tua yang memiliki anak penderita kanker mengalami kecemasan akibat perubahan dalam pengasuhan anaknya. Dan jika kecemasan tidak diatasi, orang tua menjadi tidak responsif terhadap kebutuhan anak-anak mereka sehingga semakin berdampak negatif pada kondisi anak-anak mereka.

Tujuan: penelitian ini bertujuan untuk mendeskripsikan kecemasan orang tua yang memiliki anak penderita kanker selama masa pandemi Covid-19.

Metode: penelitian ini menggunakan desain penelitian deskriptif dan non-probability sampling (teknik consecutive sampling) dengan memilih 30 responden. Penelitian ini juga menggunakan kuesioner Corona Pandemic Anxiety Scale-11 item (CPAS-11) untuk mengumpulkan data dan dianalisis menggunakan analisis univariat.

Hasil: hasil analisis dari 30 responden, mayoritas berusia dewasa awal (60\%), adalah ibu (76,7\%), pendidikan terakhir SLTA (50\%), memiliki anak dengan kanker stadium $2(53,3 \%)$, dan lama menderita anak 0-5 tahun (96,7\%). Peneliti kemudian menemukan mayoritas orang tua dalam penelitian ini (50\%) mengalami tingkat kecemasan sedang, dan mayoritas orang tua dengan tingkat kecemasan berat memiliki anak usia sekolah (6-12 tahun) (25\%), memiliki anak usia 0- 5 tahun penderitaan. (17,2\%), dan memiliki anak dengan kanker stadium 2 $(18,8 \%)$.

Simpulan: sebagian besar orang tua yang terlibat dalam penelitian ini mengalami kecemasan tingkat sedang dengan berbagai karakteristik yang menyertainya. Hasil penelitian ini dapat digunakan sebagai studi literatur bagi mahasiswa keperawatan untuk bekerjasama dengan pihak rumah sakit dalam mengembangkan dan menemukan intervensi yang tepat untuk mengatasi kecemasan pada orang tua dengan anak penderita kanker.
\end{abstract}

\section{Kata kunci:}

Kecemasan, orang tua, anak penderita kanker, pandemi Covid-19.

\section{ABSTRACT}

Backgrounds: during the Covid-19 pandemic, many parents who had children with cancer experienced anxiety due to changes in their child's care. And if the anxiety is not addressed, parents become unresponsive to their children's needs thus further negatively affect their children's condition

Purpose: this study aims to describe the anxiety of parents who have children with cancer during the Covid-19 pandemic.

Methods: this study use descriptive research design and non-probability sampling (consecutive sampling technique) to select 30 respondents. This study also used Corona Pandemic Anxiety Scale-11 item (CPAS-11) questionnaire to collect data and was analyzed using uni-variate analysis 
Results: the results of the analysis of 30 respondents, the majority are in early adulthood $(60 \%)$, are mothers $(76.7 \%)$, last education high school $(50 \%)$, have a child with stage 2 cancer $(53.3 \%)$, and the length of time the child has suffered is $0-5$ years $(96.7 \%)$. Researchers then found the majority of parents in this study $(50 \%)$ experienced moderate levels of anxiety, and the majority of parents with severe anxiety levels had children at school age (6-12 years) (25\%), had children with $0-5$ years of suffering. (17.2\%), and having a child with stage 2 cancer $(18.8 \%)$.

Conclusion: most of the parents involved in this study experienced moderate levels of anxiety with various accompanying characteristics. The result of this research can be used as a literature study for nursing students to collaborate with the hospital in developing and finding appropriate interventions to overcome anxiety in parents with children with cancer.

\section{Keywords:}

Anxiety, parents, children with cancer, Covid-19 pandemic

\section{LATAR BELAKANG}

Pandemi Covid-19 yang sedang terjadi memiliki dampak terhadap seluruh aspek kehidupan manusia /salah satunya adalah layanan kesehatan. Selama pandemi ditemukan bahwa terjadi penurunan angka kunjungan rumah sakit, pembatalan perawatan, pengalihan tenaga medis kepada penanganan kasus covid-19, pembatasan jumlah kunjungan, serta penundaan dan penutupan program perawatan (kemoterapi, screening, radiasi, pembedahan) (Kutluk et al., 2021; World Health Organisation, 2020).

Perubahan pelayanan kesehatan akibat pandemi ini juga dirasakan oleh pasien Onkologi Anak yang menyebabkan mereka mengalami pembatasan perawatan terapi serta penundaan follow up appointment (Kotecha, 2020; Kutluk et al., 2021). Kutluk et al., (2021) menemukan bahwa perubahan ini menyebabkan terjadinya penurunan angka pasien anak yang menjalani perawatan kanker, yang mana dapat menyebabkan kenaikan angka mortalitas pada anak kanker.

Hal ini tidak hanya berdampak terhadap anak, namun juga terhadap orangtua. Penelitian terdahulu menemukan bahwa orang tua mengalami kecemasan 2 kali lebih tinggi selama masa pandemi dan orang tua dengan anak penyakit kanker mengalami kecemasan karena adanya perubahan mekanisme pengobatan anaknya (A.L van Tilburg et al., 2020; Purwaningsih et al., 2020; Wimberly et al., 2021). Hal ini sejalan dengan studi penelitian yang dilakukan oleh peneliti pada tanggal 01 Maret 2021 pada 10 orang tua yang mendampingi anaknya berobat di Poli Hemato Onkologi Anak RSUD Arifin Achmad Pekanbaru melalui kuesioner didapatkan bahwa 2 kecemasan ringan, 3 kecemasan sedang, dan 1 kecemasan berat. Berdasarkan hasil wawancara juga didapatkan bahwa terdapat beberapa hal yang dapat menimbulkan rasa cemas pada orang tua seperti kondisi anak, biaya dan jangka waktu pengobatan anak yang besar, kekhawatiran akan anaknya terinfeksi virus Covid-19 saat ke Rumah sakit, serta adanya perubahan dalam prosedur perawatan akibat pandemi.

Kecemasan orang tua ini kemudian secara tidak langsung dapat mempengaruhi kondisi anaknya jika tidak diatasi. Beberapa penelitian menyatakan bahwa rasa cemas orang tua dapat mempengaruhi psikologis anaknya dan berpotensi penganiayaan pada anak serta menjadi tidak responsif terhadap kebutuhan anaknya (Budi widiarta et al., 2018; Brown et al., 2020). 
Berdasarkan uraian yang dipaparkan diatas, peneliti tertarik melakukan penelitian tentang "Gambaran tingkat kecemasan orang tua yang memiliki anak dengan penyakit kanker selama masa pandemi Covid-19".

\section{TUJUAN PENELITIAN}

Mengidentifikasi tingkat kecemasan orang tua yang memiliki anak dengan penyakit kanker selama pandemi Covid-19.

\section{METODE PENELITIAN}

Penelitian ini menggunakan jenis penelitian deskriptif sederhana dan teknik consecutive sampling. Jumlah sampel pada penelitian ini sebanyak 30 orang tua yang memiliki anak dengan penyakit kanker. Data penelitian dikumpulkan menggunakan kuesioner Corona Pandemi Anxiety Scale-11 item (CPAS-11) yang terdiri dari 11 pertanyaan dan menggunakan analisis univariat.

\section{HASIL}

Responden pada penelitian ini terdiri dari 30 responden yaitu orang tua yang mendampingi anaknya berobat atau menjalani perawatan di Rumah sakit pemerintah di Kota Pekanbaru. Dari 30 responden yang telah diteliti, didapatkan mayoritas usia responden berada pada usia dewasa awal yaitu sebanyak 18 orang $(60 \%)$. Berdasarkan peran sebagai orang tua, sebagian besar responden berperan sebagai ibu sebanyak 23 orang (76.7\%). Berdasarkan tingkat pendidikan atau pendidikan terakhir responden, didapatkan bahwa mayoritas responden dalam penelitian ini berpendidikan SMA/MAN sederajat yaitu sebanyak 15 orang $(50 \%)$. Berdasarkan stadium kanker anak, dalam penelitian ini didapatkan bahwa mayoritas responden memiliki anak dengan stadium kanker 2 yaitu sebanyak 16 orang (53.3\%), dan berdasarkan hasil penelitian didapatkan bahwa sebagian besar responden mempunyai anak dengan lama menderita kanker dalam rentang waktu 0-5 tahun yaitu sebanyak 29 orang (96.7\%).

\section{Kecemasan Orang Tua}

Tabel 1. Tingkat kecemasan orang tua yang memiliki anak dengan penyakit kanker selama pandemi Covid-19.

\begin{tabular}{ccc}
\hline Tingkat Kecemasan & Frekuensi & Presentase (\%) \\
\hline Kecemasan rendah & 10 & $33.3 \%$ \\
Kecemasan sedang & 15 & $50.0 \%$ \\
Kecemasan berat & 5 & $16.7 \%$ \\
\hline Total & 30 & $100.0 \%$ \\
\hline
\end{tabular}

Berdasarkan Tabel 1 diatas dapat diketahui bahwa dari 30 responden yang telah diteliti, didapatkan bahwa sebagian besar orang tua yang memiliki anak dengan penyakit kanker selama pandemi Covid-19 mengalami derajat kecemasan sedang yaitu berjumlah 15 orang $(50 \%)$. 
Tabel 2. Tingkat kecemasan orang tua berdasarkan usia anak.

\begin{tabular}{cccccccc}
\hline \multirow{2}{*}{ Usia anak } & \multicolumn{9}{c}{ Tingkat Kecemasan } & \multirow{2}{*}{ Total } \\
\cline { 2 - 6 } & \multicolumn{2}{c}{ Ringan } & \multicolumn{2}{c}{ Sedang } & \multicolumn{2}{c}{ Berat } & \\
\cline { 2 - 7 } & $\mathrm{N}$ & $\%$ & $\mathrm{~N}$ & $\%$ & $\mathrm{~N}$ & $\%$ & \\
\hline Toddler (1-3 tahun) & 2 & 50.0 & 1 & 25.0 & 1 & 25.0 & 4 \\
Pra-sekolah (3-6 tahun) & 3 & 37.5 & 5 & 62.5 & 0 & 0.0 & 8 \\
Sekolah (6-12 tahun) & 5 & 41.7 & 4 & 33.3 & 3 & 25.0 & 12 \\
Remaja (12-18 tahun) & 0 & 0.0 & 5 & 83.3 & 1 & 16.7 & 6 \\
\hline \multicolumn{1}{c}{ Total } & 10 & 33.3 & 15 & 50.0 & 5 & 16.7 & 30 \\
\hline
\end{tabular}

Berdasarkan Tabel 2 dapat diketahui bahwa dari 30 responden yang telah diteliti, didapatkan mayoritas responden yang mengalami derajat kecemasan berat adalah responden yang mempunyai anak pada usia anak sekolah (6-12 tahun) yaitu sebanyak 3 responden (25.0\%).

Tabel 3. Tingkat kecemasan orang tua berdasarkan lama anak menderita.

\begin{tabular}{|c|c|c|c|c|c|c|c|}
\hline \multirow[t]{3}{*}{ Lama menderita } & \multicolumn{6}{|c|}{ Tingkat Kecemasan } & \multirow[t]{3}{*}{ Total } \\
\hline & \multicolumn{2}{|c|}{ Ringan } & \multicolumn{2}{|c|}{ Sedang } & \multicolumn{2}{|c|}{ Berat } & \\
\hline & $\mathrm{N}$ & $\%$ & $\mathrm{~N}$ & $\%$ & $\mathrm{~N}$ & $\%$ & \\
\hline$>10$ tahun & 0 & $0.0 \%$ & 1 & $100.0 \%$ & 0 & $0.0 \%$ & 1 \\
\hline $0-5$ tahun & 10 & $34.5 \%$ & 14 & $48.3 \%$ & 5 & $17.2 \%$ & 29 \\
\hline Total & 10 & $33.3 \%$ & 15 & $50.0 \%$ & 5 & $16.7 \%$ & 30 \\
\hline
\end{tabular}

Berdasarkan Tabel 3 dapat diketahui bahwa dari 30 responden yang telah diteliti, didapatkan mayoritas responden yang mengalami derajat kecemasan berat adalah responden yang memiliki anak dengan penyakit kanker dengan lama waktu menderita 0-5 tahun yaitu sebanyak 5 responden (17.2\%).

Tabel 4. Tingkat kecemasan orang tua berdasarkan stadium kanker anak.

\begin{tabular}{cccccccc}
\hline \multirow{2}{*}{$\begin{array}{c}\text { Stadium Kanker } \\
\text { Anak }\end{array}$} & \multicolumn{9}{c}{ Tingkat Kecemasan } & \multirow{2}{*}{ Total } \\
\cline { 2 - 6 } & \multicolumn{2}{c}{ Ringan } & \multicolumn{2}{c}{ Sedang } & \multicolumn{2}{c}{ Berat } & \\
\cline { 2 - 7 } & $\mathrm{N}$ & $\%$ & $\mathrm{~N}$ & $\%$ & $\mathrm{~N}$ & $\%$ & \\
\hline 1 & 1 & 11.1 & 6 & 66.7 & 2 & 22.2 & 9 \\
2 & 7 & 43.8 & 6 & 37.5 & 3 & 18.8 & 16 \\
3 & 1 & 50.0 & 1 & 50.0 & 0 & 0.0 & 2 \\
4 & 1 & 33.3 & 2 & 66.7 & 0 & 0.0 & 3 \\
\hline Total & 10 & 33.3 & 15 & 50.0 & 5 & 16.7 & 30 \\
\hline
\end{tabular}

Berdasarkan Tabel 4 dapat diketahui bahwa dari 30 responden yang telah diteliti, didapatkan mayoritas responden yang mengalami tingkat kecemasan berat terdapat pada stadium kanker anak 2 yaitu sebanyak 3 responden $(18.8 \%)$. 


\section{PEMBAHASAN}

\section{Karakteristik Responden}

Berdasarkan penelitian yang telah dilakukan ditemukan bahwa mayoritas responden adalah seorang ibu (76.7\%). Hal ini didukung oleh penelitian terdahulu yang menyatakan bahwa ibu merupakan pengasuh utama bagi anak, dan perempuan lebih sering merasa cemas dikarenakan mekanisme kopingnya yang buruk dibandingkan dengan laki-laki (Alves et al., 2013; Elias et al., 2013).

Kemudian mayoritas responden dalam penelitian ini berusia pada dewasa muda (18-40 tahun (60\%). Hal ini didukung oleh penelitian yang dilakukan oleh Elias et al. (2013) yang menyatakan bahwa kecemasan juga dipengaruhi oleh usia, dimana berkaitan dengan sedikit banyaknya pengalaman individu di masa lalu dalam menghadapi masalah atau kondisi yang sama yang dapat menyebabkan kecemasan, sehingga apabila semakin tua umur seseorang maka semakin baik pula seseorang tersebut dalam mengendalikan emosinya.

Mayoritas responden dalam penelitian ini merupakan tamatan SMA/Sederajat (50\%). Tingkat pendidikan seseorang itu mempengaruhi seseorang dalam memberikan respon, dan apabila semakin tinggi tingkat pendidikan individu maka semakin banyak pengetahuannya, serta akan mempengaruhi tingkat kecemasan individu tersebut. Apabila tingkat pengetahuannya semakin baik maka tingkat kecemasannya juga semakin rendah. (Lestari 2015; Van Oers et al., 2014; Othman et al., 2011).

Mayoritas responden dalam penelitian ini merupakan anak dengan stadium kanker 2 (53.3\%). Hal tersebut dikarenakan kurangnya pengetahuan orang tua terhadap penyakit kanker dan kemiripan tanda dan gejala penyakit kanker dengan penyakit umum lainnya sehingga menyebabkan keterlambatan untuk penanganan penyakit kanker tersebut (The American Society of Clinical Oncology (ASCO), 2019).

Mayoritas responden dalam penelitian ini adalah orang tua dengan lama anak menderita kanker dalam rentang waktu 0-5 tahun (96.3\%). ASCO (2021) menyatakan bahwa angka harapan hidup pada anak kanker untuk usia remaja 15 tahun sampai 19 tahun meningkat menjadi 85\% untuk semua jenis kanker dan apabila menjalani pengobatan bertahan hidup setidaknya 5 tahun (American Cancer Society, 2021).

\section{Gambaran tingkat kecemasan orang tua yang memiliki anak kanker selama pandemi Covid-19}

Berdasarkan penelitian yang telah dilakukan didapatkan bahwa mayoritas responden $(50 \%)$ mengalami tingkat kecemasan moderate/sedang. Peneliti juga menemukan bahwa responden yang mengalami tingkat kecemasan berat adalah orang tua yang memiliki anak dengan usia anak sekolah (6-12 tahun) (25\%). Hal ini dijelaskan dengan penelitian yang dilakukan sebelumnya oleh Alves et al (2013) bahwa semakin muda usia anak maka semakin tinggi tingkat kecemasan yang dialami oleh orang tua dikarenakan anak masih bergantung terhadap orang tua nya saat menjalani perawatan dan pengobatan.

Kecemasan orang tua dapat disebabkan karena pada anak usia sekolah biasanya perkembangan kognitif anak sudah baik sehingga anak sudah bisa mengeluh dan mengekspresikan emosinya, lebih lanjut lagi anak usia sekolah biasanya sudah mulai menyadari apa yang sedang terjadi sehingga reaksi mereka terhadap penyakit kankernya akan 
sama seperti rekasi anak bayi seperti membutuhkan dukungan emosional dari orang tua, merasa tidak nyaman akibat terganggunya pekerjaan sekolah, merasa marah dan sedih karena penyakitnya mereka tidak dapat bermain seperti biasanya, dan akan menarik diri karena penyakit yang dideritanya.

Kemudian, mayoritas responden yang mengalami tingkat kecemasan berat yaitu responden yang memiliki anak dengan stadium kanker 2 (18.8\%). Hal ini dapat disebabkan karena stadium 2 merupakan stadium yang lebih kompleks dibandingkan stadium 1. Orang tua yang merawat anak dengan stadium lanjut dapat menimbulkan rasa cemas yang cukup berat dikarenakan orang tua biasanya akan merasa sedih yang berlarut-larut karena harus melihat penderitaan fisik maupun emosional anaknya (Wong, 2009; Rosenberg et al., 2013). Penelitian yang dilakukan Othman et al., (2011) juga menemukan bahwa orangtua akan memiliki tingkat kecemasan yang lebih rendah apabila hasil tes menunjukkan kondisi anak yang lebih baik.

Penemuan terakhir dalam penelitian ini yaitu didapatkan bahwa mayoritas responden dengan lama anak menderita penyakit kanker 0-5 tahun memiliki tingkat kecemasan berat $(17.2 \%)$. Sejalan dengan penelitian yang dilakukan sebelumnya oleh Norberg \& Boman (2008) yang mana dalam penelitiannya ditemukan bahwa orang tua yang memiliki anak kanker 1 tahun pertama setelah anaknya didiagnosa kanker memiliki kecemasan yang lebih tinggi dibandingkan orang tua dengan anak yang sehat, dan didapatkan bahwa kecemasan orang tua meningkat hanya dalam 2,5 tahun setelah di diagnosa.

\section{SIMPULAN}

Peneliti menemukan mayoritas orangtua dalam penelitian ini $(50 \%)$ mengalami kecemasan sedang, dan mayoritas orang tua dengan tingkat kecemasan berat memiliki anak pada usia sekolah (6-12 tahum) (25\%), memiliki anak dengan lama menderita 0-5 tahun (17.2\%), dan memiliki anak dengan stadium 2 kanker $(18.8 \%)$. Hasil dari penelitian ini daapat digunakan sebagai literatur bagi mahasiswa keperawatan untuk kolaborasi dengan rumah sakit untuk mengembangkan dan menemukan intervensi yang tepat untuk mengatasi kecemasan orang tua dengan anak kanker.

\section{REFERENSI}

Alves, D. F. dos S., Guirardello, E. de B., \& Kurashima, A. Y. (2013). Stress related to care: The impact of childhood cancer on the lives of parents. Revista Latino-Americana de Enfermagem, 21(1). https://doi.org/10.1590/S0104-11692013000100010

American Cancer Society (ACS). 2021. Key Statistics for Childhood Cancers. https://www.cancer.org/cancer/cancer-in-children/key-statistics.html. Atlanta: American Cancer Society

American Society of Clinical Oncology (ASCO). 2019. Childhood Cancer: Symptoms and Sign. https:/www.cancer.net/cancer-types/childhood-cancer/symptoms-and-signs.

Brown, S. M., Doom, J. R., Lechuga-Peña, S., Watamura, S. E., \& Koppels, T. (2020). Stress and parenting during the global COVID-19 pandemic. Child Abuse and Neglect. https://doi.org/10.1016/j.chiabu.2020.104699

Budi Widiarta, G., Martini, M., Studi, P. S., \& Sekolah Tingi Ilmu Kesehatan Buleleng, K. (2018). Kecemasan Dan Kesedihan Ibu Dalam Merawat Anak Usia Prasekolah Yang Terdiagnosa Leukemia Limfoblastik Akut Di Rsup Sanglah Denpasar. In Jurnal Kesehatan MIDWINERSLION.

Elias, Y., Susanti, I. L., \& Hayati, N. I. (2013). Faktor-Faktor yang Mempengaruhi Tingkat 
Kecemasan Keluarga di Ruang High Care Unit (HCU) Rumah Sakit Immanuel Bandung. Seminar Nasional 2013.

Kotecha, R. S. (2020). Challenges posed by COVID-19 to children with cancer. In The Lancet Oncology. https://doi.org/10.1016/S1470-2045(20)30205-9

Kutluk, M. T., Ahmed, F., Kirazlı, M., Bajin, İ. Y., Müngen, E., Ekinci, S., \& Yıldız, F. (2020). The effect of the COVID-19 pandemic on paediatric cancer care: Lessons learnt from a major paediatric oncology department in Turkey. Ecancermedicalscience. https://doi.org/10.3332/ECANCER.2021.1172

Norberg, A. L., \& Boman, K. K. (2008). Parent distress in childhood cancer: A comparative evaluation of posttraumatic stress symptoms, depression and anxiety. Acta Oncologica, 47(2). https://doi.org/10.1080/02841860701558773

Othman, A., Mohamad, N., \& Blunden, S. (2011). Factors Related to Parental Well Being in Children with Cancer. 2011 International Conference on Social Science and Humanity IPEDR, 5.

Purwaningsih, I., Aziz, A., Purnamaningsih, S. E., Margaretha, M., Karya, P., \& Yogyakarta, H. (2021). Psychology of Parents with Children with Cancer in the Covid-19 Pandemic. Annals of Tropical Medicine \& Public Health, 24(03). https://doi.org/10.36295/asro.2021.24360

Rosenberg, A. R., Dussel, V., Kang, T., Geyer, J. R., Gerhardt, C. A., Feudtner, C., \& Wolfe, J. (2013). Psychological distress in parents of children with advanced cancer. JAMA Pediatrics, 167(6). https://doi.org/10.1001/jamapediatrics.2013.628

Van Oers, H. A., Haverman, L., Limperg, P. F., Van Dijk-Lokkart, E. M., Maurice-Stam, H., \& Grootenhuis, M. A. (2014). Anxiety and Depression in Mothers and Fathers of a Chronically Ill Child. Maternal and Child Health Journal, 18(8). https://doi.org/10.1007/s10995-014-1445-8

Wimberly, C. E., Towry, L., Caudill, C., Johnston, E. E., \& Walsh, K. M. (2021). Impacts of COVID-19 on caregivers of childhood cancer survivors. Pediatric Blood and Cancer. https://doi.org/10.1002/pbc.28943 